\title{
Can the WRAT-4 Math Computation Subtest Predict Final Grade in College-Level Science
}

\author{
Robert John Zagar ${ }^{1}$, Joseph W. Kovach ${ }^{2}$, Ahmed Lakhani $^{3}$, Tracy Stone ${ }^{4}$, Ishup Singh ${ }^{5}$, Mariana Portela ${ }^{6}$ \\ $\&$ Bernie Berroa $^{5}$ \\ ${ }^{1}$ Ph.D., M.P.H., Juvenile Division, Circuit Court of Cook County, USA \\ ${ }^{2}$ Psy.D., Calumet College of St. Joseph, USA \\ ${ }^{3}$ Ph.D., Calumet College of St. Joseph, USA \\ ${ }^{4}$ M.S., Calumet College of St. Joseph, USA \\ ${ }^{5}$ B.A., Calumet College of St. Joseph, USA \\ ${ }^{6}$ B.S., Calumet College of St. Joseph, USA \\ Correspondence: Robert John Zagar, Ph.D., M.P.H., Juvenile Division, Circuit Court of Cook County, USA
}

Received: September 24, 2018 Accepted: October 12, 2018 Online Published: October 25, 2018

doi:10.5539/res.v10n4p144 URL: https://doi.org/10.5539/res.v10n4p144

\begin{abstract}
Seventy-one, freshman through senior undergraduate college students 28 males and 43 females, $M$ age $=22.34$ yr., $S D=$ 4.20 in 5 different science classes were administered the Wide Range Achievement Test Fourth Edition (WRAT-4) Math Computation Subtest. Predictive validity coefficients were calculated relative to the criterion of the final class grade. The validity coefficient for the pre-course WRAT score was statistically significant. The WRAT-4 Math subtest can be used by instructors to examine performance on specific items to judge the appropriateness of a student's placement in either entry-level or advanced science courses. However, high school grades are also a good predictor of completing the college curriculum and should be used along with math computation skills scores. Also motivation to complete college level science courses and socioeconomic status may be covariates in predicting college science final grade and eventual graduation from college.
\end{abstract}

Keywords: math computation, prediction, college science course final grade

\section{Introduction}

Discovering the factors related to why students drop out of college science courses is an important goal nationwide. With the current shortage of engineers and scientists, college science dropout is a costly liability requiring recruiting foreign trained engineers and scientists. Given the high failure rate of foreign trained engineers and scientists, preparing more native born engineers and scientists is a high priority.

Students have increased lifetime earnings potential upon graduation from college, with improved standard of living and increased productivity and efficiency. Retaining more science student has been studied intensively, but with little improvement in graduation rates. Given that student engagement and interest is the single most important factor in staying in college science courses (Tinto, 2006), and that college math is one of the more difficult endeavors in the college (Parker, 2004), proficiency in algebra and math, staying in a science college curriculum, and graduation seem to be linked (Madison, Linde, Decker, Rigsby, Dingman, and Stegman, 2015; Renaissance, 2017; 2018).

The United States teaches more math and science than other countries globally and rich American students perform equally compared to other nation's students (Brown and Brown, 2007). Attitude towards math and math test performance predict college math course success (Chen, Bai, Battista, Qin, Chen, Evans and Menon, 2018). Math skills and math course grades predict college science course success (Irman, Nasor, and Hayati, 2012; Hudson and Rottman, 1981). High school and college math and science grades plus ability tests predict college science course success (Malo, 1976; Nordstrom, 1990; Creech and Sweeder, 2012; Pembridge and Verleger, 2013; Flurry, 2015; Hodara and Lewis, 2017; Schaffhauser, 2017). Socioeconomic status, namely sufficient funds to complete college determine graduation.

If reliable and valid objective information concerning math achievement predictive of success in college science courses were available, progress could be made toward correct placement and better retention of college engineering and science students. This will not only benefit the college science student, but also assist college admission committees' selections of 
those best suited for science careers in curricula where math is crucial and college science faculty for planning purposes. Historically, some colleges admit by qualified open admission those applicants who do not have course prerequisites. The goal of this paper is to determine whether a math computation achievement test could predict college science course grade confirming prior research.

\section{Methods}

Participants: Data were gathered from a convenience sample of 71 undergraduate science students (28 men, 43 women) with a M age $=22.34$ (S.D. =4.20) years old at Calumet College of Saint Joseph. The sample was made of 17 African American students, 37 White American, 16 Hispanic American, and 1 Asian American student. All research participants were admitted to college through conventional qualified open admissions processes. See Table 1.

Table 1. Demographic Characteristics of 71 College Science Students

\begin{tabular}{lcc}
\hline & $\%$ & $n$ \\
\hline Male & 39 & 28 \\
Female & 61 & 43 \\
Race & & \\
African American & 24 & 17 \\
Asian American & 1 & 1 \\
White American & 52 & 37 \\
Hispanic American & 23 & 16 \\
Age, M $_{\text {age yr.S.D.age yr. }}$ & 22.34 & 4.20 \\
\hline
\end{tabular}

Measures: The Wide Range Achievement Test-Fourth Edition (WRAT-4) Math Computation Subtest (Wilkinson and Robertson, 2004). Test-retest reliability was .87 for the two alternate forms used. The WRAT -4 assesses basic academic skills necessary for effective learning, communication, and thinking, including performing basic math calculations. The WRAT -4 contains subtests of Letter and Word Recognition, Sentence Comprehension, Spelling, and Math Computation; only the latter was administered in this study. Math Computation evaluates the person's performing basic arithmetic skills through counting, identifying numbers, solving simple oral problems, and calculating written math problems in addition, subtraction, multiplication, division, fractions, decimals, and algebra. It is based on a representative national sample of over 3,000 persons, aged 5 to 94 years, selected according to a stratified national sampling procedure with proportionate allocation controlled for age, gender, ethnicity, geographical region, and educational attainment as an index of socioeconomic status. The WRAT-4 has scaled scores, percentiles, stanines, normal curve equivalents, Rasch ability scaled scores, age-based, and grade-based norms, increasing the usefulness of the tests in Grades K-12. The age-based norms start at five years and extend to a maximum age of 94 years. With easy administration and scoring, a significant amount of information is gained from a relatively brief investment of testing time. The alternate forms can be used interchangeably with comparable results or combined into a single examination. Administration time for five to seven-year-olds is 15 to 20 minutes, and for 8 years and older, 30 to 45 minutes. The WRAT- 4 allows for collecting initial data, screening large groups, diagnosis of specific learning disorders, evaluating cognitive disorders, pre- and post-testing, assessing academic progress, and determining minimal proficiency for educational and/ or vocational settings. For the WRAT -4 Math Computation Subtest, Cronbach's $\alpha=.87$. Concurrent validity with the Wechsler Individual Achievement Test Second Edition (WIAT-II) has been reported as $r=.92(p<.01$; Wechsler, 2001).

Grades: Raw test scores on the WRAT-4 Math Computation Subtest were obtained. At the end of the semester, final grades were calculated by the course instructor and submitted, in accordance with the course syllabus and college catalogue.

Procedures: The WRAT-4 Math Computation subtest was administered soon after the course began. Participants' science course grades were compared with the results of the WRAT-4 Math Computation Subtests. Scores from the WRAT-4 Math Computation Subtest met the assumptions of multiple regression analysis, namely, being normally distributed with statistically significant $(p<.01)$ homogeneity of variance. The math computation scores were subjected to simple regression analysis, with the final numerical course grade as the criterion.

\section{Results}

As shown in Table 2, correlations and beta coefficients are consistent with the fact that the WRAT-4 Math Computation Subtest was a statistically significant predictor of success in these college science courses. WRAT-4 Math Computation 
Subtest scores accounted for a statistically significant $(p<.01)$ proportion of the criterion variance $(8.3 \%)$. The mean pre-course WRAT-4 Math Computation Subtest raw score for the group of students who passed was 43.26 $(S D=5.29)$, and for those who failed $30.14(S D=3.76)(t=3.62, p<.01)$.

Table 2. Coefficients for Variable Entered Hierarchically Into Regression Analysis to Predict

Final College Science Grade

\begin{tabular}{|c|c|c|c|c|c|c|}
\hline & \multirow{3}{*}{ Model } & & & \multicolumn{3}{|c|}{$\begin{array}{c}\text { Standardized Unstandardized } \\
\text { Correlation }\end{array}$} \\
\hline & & \multicolumn{2}{|c|}{ Coefficients } & \multirow{2}{*}{$\begin{array}{c}\text { Coefficients } \\
\beta\end{array}$} & \multirow[t]{2}{*}{$t$} & \multirow[t]{2}{*}{$p$} \\
\hline & & B & $S E$ & & & \\
\hline \multirow[t]{2}{*}{ Model 1} & (Constant) & 59.03 & 7.89 & & 7.49 & .01 \\
\hline & WRAT-4 Math & 0.66 & 0.18 & .42 & 3.62 & .01 \\
\hline
\end{tabular}

Note In Model 1, the WRAT-4 Math Computation score was used as a predictor or independent variable. The dependent variable (to be predicted) was the final college science grade.

\section{Discussion}

The results of this study are consistent with the hypothesis that the WRAT-4 Math Computation Subtest is a valid predictor of passing a college level science course. However, given that overall high school grades have a correlation coefficient of .37 with college grades (Zwick and Sklar, 2005), as compared with the .42 found in this study, continued use of the WRAT-4 Math Computation Subtest as a screening test for students taking different college level science courses seems warranted if used along with high school grades. Since the university already uses an objective test at admission for verbal and math achievement, perhaps adding another test may be redundant. Although the WRAT-4 Math Computation Subtest only takes 10 to 15 minutes to administer in the science course and its cost is minimal, its overall simple prediction of a pass/fail outcome is as good as high school grades, which both explain approximately $40 \%$ of the variance in completing college level science classes successfully (Zwick and Sklar, 2005).

Since the WRAT-4 Math Computation Subtest material is similar to what is learned in high school curricula, the individual's ability to perform basic math skills through counting, identifying numbers, solving simple oral problems, and calculating written math problems in addition, subtraction, multiplication, division, fractions, decimals, and algebra, is of qualitative value for instructors, who can examine the test booklets to see if individual college students can perform such problems. Thus, the instructor can act as a safeguard by assigning additional practice on specific types of problems, or offering tutoring to individual students, or explaining to students the value of moving to a lower level class. Perhaps also math and science college instructors might wish to use Khan academy to supplement skills already learned in high school or early college classes since the 10 to 20 minute youtube.com vignettes are easy to understand and students can repeat the lessons online as many times as needed to understand the basic concepts since some pupils are quick learners and others require repetition. The major limitation of this study was the small, non-random sample. The findings here may not generalize to all American science college students. Predicting college success is challenging, but some of the problems associated with admitting unprepared students may be ameliorated by allowing instructors to use additional testing and to advise specific students to obtain tutoring or take preparatory classes or watch Khan Academy youtube.com vignettes tailored to their level of success as shown on objective math tests.

Table 3. Summary of Hierarchical Regression Analysis for Final College Science Grade

\begin{tabular}{|c|c|c|c|c|c|c|c|c|c|}
\hline \multirow[b]{2}{*}{ Model } & \multirow[b]{2}{*}{$R$} & \multirow[b]{2}{*}{$R^{2}$} & \multirow[b]{2}{*}{$\begin{array}{c}\text { Adjusted } \\
\qquad R^{2}\end{array}$} & \multirow[b]{2}{*}{$\begin{array}{r}S E \text { of } \\
\text { Estimate }\end{array}$} & \multirow{2}{*}{$\begin{array}{l}\text { Change } \\
R \\
\text { Change }\end{array}$} & \multicolumn{4}{|c|}{ Statistics } \\
\hline & & & & & & $\begin{array}{c}F \\
\text { Change }\end{array}$ & $d f_{1}$ & $d f_{2}$ & $p$ \\
\hline 1 & .37 & .175 & .162 & 7.60 & .175 & 13.14 & 1 & 62 & .01 \\
\hline
\end{tabular}




\section{References}

Brown, A. S., \& Brown, L. L. (2007). What Are Science \& Math Test Scores Really Telling U.S.? The Best of Tau Beta Pi, winter, 13-17. Retrieved at: https://www.tbp.org/pubs/Features/W07Brown.pdf

Chen, L., Bai, S. R., Battista, C., Qin, S., Chen, T., Evans, T. M., \& Menon, V. (2018). Positive attitude towards math supports early academic success: behavioral evidence and neurocognitive mechanisms, Developmental Psychology.

Creech, L. R., \& Sweeder, R. D. (2012). Analysis of student performance in large-enrollment life science courses. CBE Life Science Education, 11, 386-391.

Hodara, M., \& Lewis, K. (2017) How well does high school grade point average predict college performance by student urbanicity and timing of college entry? Institute of Education Sciences, U.S. Department of Education (February). Retrieved at: https://edexcellence.net/articles/do-grades-or-test-scores-better-predict-new-students\%E2\%80\%99-success-in -credit-bearing-college

Hudson, H. T., \& Rottman, R. M. (1981). Correlation between performance in physics and prior mathematics knowledge, Journal of Research in Science Teaching, 18, 291-294. https://doi.org/10.1002/tea.3660180403

Imran, A., Nasor, M., \& Hayati, F. (2012). Relating Grades of Math and Science Courses with Students' Performance in a Multi-Disciplinary Engineering Program - A Gender Inclusive Case Study. Procedia-Social and Behavioral Sciences, 46, 3989-3992. https://doi.org/10.1016/j.sbspro.2012.06.184

Madison, B. L., Linde, C. S., Decker, B. R., Rigsby, E. M., Dingman, S. W., \& Stegman, S. E. (2015). A Study of Placement and Grade Prediction in First College Mathematics Courses, PRIMUS, 25(2), 131-157. https://doi.org/10.1080/10511970.2014.921653

Malo, D. D. (1976). Relationships between course performance and student backgrounds I in an introductory soil science course. Journal of Agronomic Education, 6, 20-24.

Nordstrom, B. H. (1989). Predicting Performance in Freshman Chemistry, (p. 15).

Parker, M. (2004) Placement, retention, and success: a longitudinal study of mathematics and retention. Journal of General Education, 54, 22-40. https://doi.org/10.1353/jge.2005.0016

Pembridge, J. J., \& Verleger, M. A. (2013). First-Year Math and Physics Courses and their Role in Predicting Academic Success in Subsequent Courses, 120nd American Society for Engineering Education Annual Conference and Exposition, Atlanta, Georgia. Retrieved at: file:///C:/ /Downloads/Pembridge_Verleger_ASEE_2013\%20(1).pdf

Renaissance. (2017). Trends in student outcome measures: The role of individualized math practice. Wisconsin Rapids, WI: Author.

Renaissance. (2018). Math milestones: The critical role of math achievement in student success. Author. Retrieved at: https://www.renaissance.com/2018/03/22/blog-math-milestones-critical-role-math-achievement-student-success I

Schaffhauser, D. (2017). GPA Versus Exam Scores: What's Better in Predicting College Success? The Journal. March, 9. Retrieved at: https://thejournal.com/articles/2017/03/09/gpa-versus-exam-scores.aspx

Tinto, V. (2006) Research and practice of student retention: what's next? Journal of College Student Retention, 8 , 1-19. https://doi.org/10.2190/4YNU-4TMB-22DJ-AN4W

Wechsler, D. (2001) Wechsler Individual Achievement Test manual. New York: Psychological Corp.

Wilkinson, G. S., \& Robertson, G. J. (2004) Wide Range Achievement Test Fourth Edition (WRAT-4) professional manual. Lutz, FL: Psychological Assessment Resources, Inc.

Zwick, R., \& Sklar, J. C. (2005) Predicting college grade and degree completion using high school grades and SAT scores. American Educational Research Journal, 42, 439-464. https://doi.org/10.3102/00028312042003439

\section{Copyrights}

Copyright for this article is retained by the author(s), with first publication rights granted to the journal.

This is an open-access article distributed under the terms and conditions of the Creative Commons Attribution license (http://creativecommons.org/licenses/by/4.0/). 